\title{
UN DESCONOCIDO COPISTA DE MURILLO: EL CAPUCHINO FR. PEDRO DE MADRID (1880-1936)
}

\section{AN UNKNOWN COPYST OF MURILLO: CAPUCHIN FR. PEDRO DE MADRID (1880-1936)}

\author{
José JAVIER AzAnZa LóPEZ \\ Universidad de Navarra. España \\ jazanza@unav.es
}

\begin{abstract}
Los conventos capuchinos de Pamplona y Sangüesa custodian un conjunto de lienzos inéditos que copian obras de Bartolomé Esteban Murillo, realizados en la segunda década del siglo XX con destino al Colegio de Lekaroz (Navarra) por el capuchino Fr. Pedro de Madrid (1880-1936), personaje de sorprendente biografía cuyas aptitudes artísticas abarcaron igualmente la música y la fotografía. El objetivo de este trabajo es dar a conocer tal legado, en el que Fr. Pedro de Madrid se revela como un hábil intérprete del pintor sevillano, así como las vicisitudes de su ejecución en Madrid y Sevilla y su posterior devenir hasta la actualidad.

Palabras clave: pintura, siglo XX, capuchinos de Sevilla y Navarra, Fr. Pedro de Madrid, Bartolomé Esteban Murillo.
\end{abstract}

The Capuchin Convents of Sangüesa and Pamplona have in their custody a group of unknown paintings copies of Bartolomé Esteban Murillo's artworks, made in the second decade of the 20th century for the College of Lekaroz (Navarra) by Capuchin Fr. Pedro de Madrid, man of amazing biography whose artistic skills also extended to music and photography. The objective of this paper is to present this legacy, in which Fr. Pedro de Madrid shows himself to be a skilful interpreter of the Sevillian artist, as well as the vicissitudes of its execution in Madrid and Seville and its subsequent evolution to the present day.

Keywords: Painting, 20th Century, Capuchins of Seville and Navarre, Fr. Pedro de Madrid, Bartolomé Esteban Murillo.

Resulta bien conocida la proliferación de copias de los temas creados por Bartolomé Esteban Murillo, encaminadas a satisfacer la intensa demanda de las órdenes religiosas o de la devoción privada que gustaba de las representaciones del pintor sevillano. En este contexto se inscribe un conjunto de lienzos ejecutados a 
comienzos del siglo XX por el capuchino Fr. Pedro de Madrid con destino al Colegio de Lekaroz, en el Valle de Baztán (Navarra).

\section{FR. PEDRO DE MADRID: BREVE SEMBLANZA BIOGRÁFICA}

Fr. Pedro de Madrid, en el siglo Pedro Satué Blanco, nació el 31 de enero de 1880 en el n $n^{\circ} 3$ de la madrileña calle del Reloj, en el seno de una familia de clase media que se completaba con otros dos hermanos. Su padre, Pedro Satué y Arreo, era funcionario en la Secretaría del Senado, y su madre, Manuela Blanco, procedía de una familia burguesa abulense ${ }^{1}$.

La temprana muerte de su padre en 1893 significó su ingreso en el Colegio de Lekaroz, recién fundado por el P. Joaquín $\mathrm{M}^{\mathrm{a}}$ de Llevaneras, Provincial de los capuchinos de Castilla y máximo responsable de la Procura de Misiones Districtus Nullius Matritense $e^{2}$. Debemos tener en cuenta que existían en Madrid círculos sociales que colaboraban en los proyectos de Llevaneras; probablemente su madre pertenecía a uno de ellos y, al enviudar, acordó con el fundador enviarlo al Colegio, un internado que compaginaba la formación de vocaciones religiosas con la de bachilleres y estudiantes de Comercio, y que en sus principios se nutrió de hijos de bienhechores de los capuchinos.

Una vez en Lekaroz, Pedro Satué cursará siete años de formación previos a su ingreso en la orden, hasta que en enero de 1900 recibe el hábito e inicia el noviciado, adoptando el nombre de Fr. Pedro de Madrid ${ }^{3}$. El 25 de febrero de 1906 es ordenado sacerdote en el solemne Triduo de aniversario por la beatificación de los mártires Agatángel de Vendôme y Casiano de Nantes, acto presidido por un cuadro de los beatos pintado por él que recibió los elogios del pintor Santiago Arcos y Ugalde 4 .

${ }^{1}$ LASA, José Antonio: Estadística de la Provincia Capuchina de Navarra-CantabriaAragón: 1900-2006. Pamplona, 2006, p. 64; AZANZA LÓPEZ, José Javier y SAN MARTÍN CASI, Roberto: "Casa, familia, heredad. La colección fotográfica de caseríos vascos de Fr. Pedro de Madrid, 1912", Revista de Dialectología y Tradiciones Populares, LXVIII-2, 2013, pp. 385-422. Mi agradecimiento a Roberto San Martín y a José Ángel Echeverría (O.F.M. Cap.) por la información facilitada.

2 Hasta su disolución en 1907, el Districtus Nullius Matritense estuvo integrado por los conventos madrileños de Jesús de Medinaceli y de El Pardo, y el Colegio de Lekaroz. ZUDAIRE HUARTE, Eulogio: Lekaroz: Colegio Nuestra Señora del Buen Consejo (18881988). Burlada, 1989, pp. 60-62.

3 AHPCP. FCL (Archivo Histórico-Provincial de Capuchinos de Pamplona. Fondo Colegio Lekaroz). Actas de imposición del Sto. Hábito capuchino a los novicios del Distrito de Madrid y Misiones de Ultramar, $\mathrm{n}^{\circ}$ 72, p. 36.

4 "Desde Lecároz", La Constancia, 1-3-1906, p. 1; El Mensajero Seráfico, 1-5-1906, p. 153.

LABORATORIO DE ARTE 28 (2016), pp. 455-479, ISSN 1130-5762

e-ISSN 2253-8305 - DOI http://dx.doi.org/10.12795/LA.2006.i.01.24 
Sus cualidades artísticas no pasaron desapercibidas a los responsables del Colegio, máxime cuando en Lekaroz se cuidaba con esmero la cualificación de sus frailes en aquellas materias en las que sobresalían; conviene recordar que en sus primeros años el centro acogió a un elenco de religiosos que cultivó con vigor las artes, entre quienes el de mayor relevancia fue el compositor y musicólogo P. Donostia $^{5}$. En nuestro caso, el estímulo venía reforzado por prescripción facultativa, dado que Fr. Pedro de Madrid padecía una enfermedad neurológica crónica, diagnosticada como síndrome de Krishaber, que aconsejaba el desempeño de actividades pausadas como las artes. Siguiendo la política de formación continua característica del centro, entre 1904 y 1918 realizará sucesivas estancias fuera del Colegio para perfeccionar sus aptitudes: San Sebastián, Madrid, Córdoba y Sevilla serán sus lugares de destino.

Precisamente a su regreso del periplo andaluz, en otoño de 1918, comunica a sus superiores la decisión de abandonar la fraternidad capuchina. Varios factores pesaron en este cambio de rumbo vital, entre ellos su precario estado de salud ante el húmedo clima baztanés -meses atrás había solicitado infructuosamente su traslado a la Provincia de Andalucía, adjuntando sendos certificados médicos firmados en Madrid y Sevilla ${ }^{6}$ - y circunstancias familiares dolorosas, como la muerte de su hermano Emilio ${ }^{7}$ y la soledad de su hermana Carmen, que regentaba en Madrid una prestigiosa sombrerería y salón de moda ${ }^{8}$.

El 1 de septiembre de 1919 regresa a la vida secular, recuperando su nombre civil. Deja temporalmente de ser fraile, aunque no su condición de sacerdote, y se

${ }_{5}^{5}$ ANSORENA MIRANDA, José Luis: Aita Donostia. Donostia, 1999, pp. 17-56.

${ }^{6}$ El primero de ellos estaba firmado en Madrid -adonde se había trasladado por un asunto familiar- el 30 de enero de 1918 por el doctor en Farmacia y médico cirujano Rafael Ortega, quien señalaba que "el R. P. Pedro de Madrid padece además de neuroartritismo, neuropatía cerebral de Krishaber, siendo necesaria la residencia en un clima cálido, de poca variación térmica durante el día, habiéndole aconsejado Andalucía, sitios análogos a Málaga, Córdoba, Sevilla, Alicante...". El segundo, en Sevilla el 18 de mayo por Antonio Fernández Peñalosa, profesor de Medicina y Cirugía, quien certifica que "el R. P. Pedro de Madrid padece de neuroartritismo con debilidad cerebral, por lo que le hemos aconsejado que resida en un clima semitropical como Andalucía (Córdoba o Sevilla), siéndole perjudicial su residencia en climas más fríos". AHPCP. FCL. Carpeta personal (Pedro Satué Blanco). Carta de Pedro de Madrid al Min. P. Provincial Antonio de Iroz, Sevilla, 16-8-1918.

${ }^{7}$ Emilio Satué, veterinario militar de profesión y artista de vocación (cultivó el dibujo y la escultura), falleció en diciembre de 1918, tal y como recogen El Globo, 16-12-1918, p. 3; y El Heraldo Militar, 17-12-1918, p. 3.

${ }^{8}$ Así lo hacía saber en sendas cartas dirigidas al Obispo de Madrid-Alcalá Prudencio Melo en junio de 1919. AHDM (Archivo Histórico Diocesano de Madrid). Caja sign. 24646/42. Expediente de D. Pedro Satué. Carta de Fr. Pedro de Madrid dirigida al Sr. Obispo de Madrid-Alcalá. Tudela, 16-6-1919; y Tudela, 28-6-1919. 


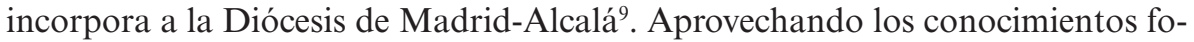
tográficos adquiridos en Lekaroz pronto encuentra trabajo como fotoperiodista en la revista ilustrada La Estrella del Mar, a la vez que se inscribe en la Real Sociedad Fotográfica de Madrid -en 1922 utilizó su laboratorio en 54 ocasiones, siendo el segundo socio que mayor uso hizo de él ${ }^{10}-$ y publica sus primeras fotografías con la firma "Fot. Satué" en ABC, Blanco y Negro y La Esfera.

Las colaboraciones de este período son en su mayor parte noticias de actividades benéficas y eventos religioso-culturales de la alta sociedad madrileña, sin descuidar el retrato, entre los que sobresale el del rey Alfonso XIII contemplando el Campo del Moro desde los balcones del Palacio Real ${ }^{11}$. Asimismo, sus fotografías de ambiente rural captadas en Lekaroz servirán para ilustrar artículos en defensa del tradicionalismo español, cuyos valores resultan extrapolables a todo el país, al punto de que la imagen de un baserritarra baztanés se emplea en un texto exaltador del campesino andaluz ${ }^{12}$ (Figura 1).

Gracias a sus contactos en los círculos aristocráticos, en 1924 el Patriarca de las Indias lo admite entre los presbíteros de la Real Capilla, cargo que le permitirá una dedicación plena a la fotografía. Ese mismo año abre un estudio con el nombre comercial de Antsa en un inmueble de la calle del Conde de Peñalver 19 (actual Gran Vía, 8), zona céntrica y en proceso de expansión ${ }^{13}$. Cabe pensar que la elección del nombre fuera un homenaje a sus años en Lekaroz, por cuanto antza significa en euskera "semejanza, parecido, apariencia", lo cual puede interpretarse como un guiño a la condición de la fotografía, y más concretamente del retrato, faceta principal de su negocio, especializándose en retratos infantiles y bodas aristocráticas.

Hacia 1928 observamos un incremento de sus colaboraciones en la prensa gráfica y, lo que supone una mayor novedad, en publicaciones de ideología mucho

${ }^{9}$ En 1921 ejerce como sacerdote adscrito a la iglesia de San Pascual de Madrid; como tal figura en una lista de suscriptores en ayuda a unos niños huérfanos tras una tragedia acaecida pocas fechas antes. "Homenaje nacional", $A B C$, 19-6-1921, p. 17.

${ }^{10}$ MARTÍN LÓPEZ, Ana María y MUÑOZ GARCÍA, Manuel: Historia de la Real Sociedad Fotográfica. Segovia, 2004, p. 48.

11 "Una fotografía del Rey", La Esfera, no 344, 7-8-1920, p. 24. En su exhaustiva tesis sobre La Esfera, Sánchez Vigil sitúa a Satué entre los fotógrafos vascos, en torno a la Casa Lux; mas no llega a relacionarlo con Fr. Pedro de Madrid, ni con la posterior firma fotográfica Antsa. SÁNCHEZ VIGIL, Juan Miguel: La documentación fotográfica en España. Revista La Esfera (1914-1920). Madrid, 1995, p. 305. Referencias del mismo autor a Satué y Antsa en La Esfera. Ilustración mundial (1914-1931). Madrid, 2003, pp. 338 y 361.

12 FERNÁNDEZ PIÑERO, Julián: "El hombre extático", La Esfera, no 347, 28-81920, p. 28.

${ }^{13}$ Una noticia-anuncio insertada en La Época, 29-5-1924, p. 2, y 31-5-1924, p. 3, se hacía eco del acontecimiento: "El distinguido sacerdote y artista don Pedro Satué ha inaugurado en la Avenida de Peñalver, 19, y Víctor Hugo, 1, con el nombre de Antsá, un gran estudio de fotografía". 
más variada, vinculándose al mundo del espectáculo, al ambiente teatral y de la revista madrileña merced a sus retratos de cantantes, actrices y cupletistas, con mención especial para Celia Gámez, de quien adquirió la condición de retratista oficial. Destaca por la fuerza de la imagen y por su carácter pictórico el de los hermanos Álvarez Quintero (Figura 2), realizado para Estampa como ilustración de un artículo del escritor y periodista sevillano Juan González Olmedilla con motivo del homenaje por el XL aniversario del estreno de su primera comedia, Esgrima y amor ${ }^{14}$.

La última fotografía de Antsa que conocemos data del 4 de diciembre de $1932^{15}$, fecha a partir de la cual su rastro se pierde de forma abrupta hasta el momento de su muerte en Madrid en $1936^{16}$. La hipótesis más probable-salvo percance fatal en la Guerra Civil- es que se agravara la enfermedad neurológica que padecía, de tal modo que quedara impedido para desempeñar su actividad fotográfica; quizás incluso se viera obligado a ingresar en algún centro sanitario hasta el final de sus días.

\section{FORMACIÓN ARTÍSTICA EN LEKAROZ: MÚSICA, FOTOGRAFÍA Y PINTURA}

El Colegio de Lekaroz fue concebido desde sus orígenes como un centro de enseñanza moderno, tanto en las materias impartidas como en los métodos de aprendizaje, con gabinetes científicos, talleres de arte y de música ${ }^{17}$ y laboratorio de fotografía; de ahí que se convirtiera en el escenario idóneo para que Fr. Pedro de Madrid pudiese desarrollar sus cualidades artísticas. Entre estas se encontraba la música, dado que, además de tener condiciones para el canto, tocaba el contrabajo y el violonchelo, acompañando las solemnes funciones religiosas ${ }^{18}$ y las veladas musicales en las que participaba como instrumentista y cantante de zarzuela ${ }^{19}$.

\footnotetext{
${ }^{14}$ Estampa, no 6, 7-2-1928, pp. 19-20.

15 "Actrices españolas. Josefina Tapias", $A B C$, 4-12-1932, p. 17.

16 Dato recogido en el Catálogo de ex colegiales de Lecároz; 1891-1967, Lecároz, 1967, p. 415.

${ }^{17}$ El P. Llevaneras montó un taller de escultura y un salón de dibujo bien dotado de mobiliario y de modelos clásicos en escayola. ZUDAIRE HUARTE, Eulogio: Lekaroz..., op. cit., p. 76. Lo corroboran fotografías de la época y un artículo publicado en La Avalancha, no 380, 7-1-1911, p. 9.

${ }^{18}$ En la Crónica del P. Emiliano de Andoáin (AHPCP. FCL) abundan las referencias a su participación musical en las solemnidades religiosas. Así, el 14-7-1907, fiesta de san Buenaventura, interpretó al violonchelo una melodía de Beethoven durante el ofertorio; el 26-2-1911 se cantó la misa de Perosi con acompañamiento de armonium y contrabajo que tocó Fr. Pedro de Madrid, ceremonia que volverá a repetirse el 17-8-1915 con motivo de la onomástica del P. Rector Joaquín Mª de Beriáin, y el 4-10-1918.

${ }^{19}$ Siguiendo al P. Andoáin, en una de esas veladas celebrada el 23-1-1909 estrenó una pieza para violonchelo compuesta por el P. Donostia; y en otra ocasión, el 5-1-1911,
} 
Más relevante resultó su vocación fotográfica, en cuya técnica se inició de la mano de Fr. Antonio de Antequera ${ }^{20}$, pionero y responsable del laboratorio fotográfico de Lekaroz ${ }^{21}$. Si bien la mayor parte de sus fotografías recogen escenarios, personas y acontecimientos, en una labor tanto promocional como testimonial del devenir cotidiano del Colegio, el talante más artístico que documental de Fr. Pedro le llevará a ampliar su horizonte e, influenciado por el pictoralismo, a crear composiciones narrativas que trascienden de la realidad, con existencia estética propia. Explícito de ello resulta su colección de veinticuatro fotografías de caseríos baztaneses con la que concurrió, bajo el lema Echezarra (Casa vieja, en euskera), al Certamen Fotográfico-Social organizado en Pamplona en julio de 1912, en el marco de la VI Semana Social y de los actos conmemorativos del VII Centenario de la batalla de las Navas de Tolosa ${ }^{22}$. El jurado otorgó dos de los galardones más importantes a la colección de Fr. Pedro: primer premio en la categoría de caseríos vascos (250 pesetas) y primer premio especial para aficionados (200 pesetas). A la vista de su posterior devenir profesional, no cabe duda de que el reconocimiento adquirido en Lekaroz como fotógrafo resultó clave a la hora de buscar espacios más abiertos en los que desarrollar su vitalidad artística.

A la música y fotografía debemos añadir su interés por la pintura, ámbito en el que Fr. Pedro de Madrid tuvo sus primeros contactos con Fr. Antonio de Vera ${ }^{23}$, responsable del taller de escultura, y probablemente con el pintor aragonés Ramiro Ros Ráfales ${ }^{24}$, quien entre 1896 y 1898 pasó varias temporadas en Lekaroz

formó parte del reparto de la zarzuela Los dos ciegos del compositor madrileño Francisco Asenjo Barbieri.

${ }^{20}$ Fr. Antonio de Antequera (1854-1937) fue responsable del laboratorio fotográfico hasta su marcha en 1908 con destino al convento de Arenys de Mar. ZUDAIRE HUARTE, Eulogio: Lekaroz..., op. cit., pp. 100-101.

${ }^{21}$ El Colegio dispuso desde sus comienzos de un avanzado taller de fotografía, con cámaras y lentes de la marca alemana Carl Zeiss, placas y negativos de cristal de la casa Bonne Presse de París, y un laboratorio compuesto por tres estancias para cámara lenta y el revelado en todas sus fases. AZCONA, Tarsicio de: "La fotografía en el Colegio de Lecároz (Baztán)", Fotografía en Navarra: fondos, colecciones y fotógrafos. Cuadernos de la Cátedra de Patrimonio y Arte Navarro, 6, 2011, pp. 397-414.

22 AZANZA LÓPEZ, José Javier: La memoria de la memoria, 1212-1912. Tras las huellas artísticas del VII Centenario de las Navas de Tolosa. Pamplona, 2012.

${ }^{23}$ Fr. Antonio de Vera (1852-1942) fue un prolijo escultor de la orden, como demuestra la cantidad de imágenes de santos y Divinas Pastoras que realizó para numerosos conventos. ZUDAIRE HUARTE, Eulogio: Lekaroz..., op. cit., p. 101.

${ }^{24}$ Ramiro Ros Ráfales (Caspe, Zaragoza, 1871-Guadalajara, 1927) tuvo una primera formación con su padre, el pintor y profesor de dibujo Manuel Ros. En 1887 ingresó en la Escuela Especial de Pintura, Escultura y Grabado de Madrid, y fue discípulo de Carlos de Haes y Luis de Madrazo; también se registra en el Museo Nacional del Prado, donde entre 1889 y 1892 copia obras de Tintoretto, José Benlliure, Francisco Pradilla y Muri1lo. Cultivó el paisaje, la pintura religiosa y la escena costumbrista, y colaboró con sus 
realizando diversos encargos ${ }^{25}$. Esta formación inicial tendrá continuidad con su estancia durante el curso 1904-1905 en Madrid, recibiendo clases de un maestro pintor -del que no llegamos a saber su nombre- y ejecutando diversos retratos con destino al Colegio ${ }^{26}$; y, posteriormente, en San Sebastián en el verano de $1910^{27}$, perfeccionando sus conocimientos en el estudio de Santiago Arcos ${ }^{28}$.

La vocación pictórica del capuchino desplegó en Lekaroz una doble vía de actuación: por un lado, ejerció como profesor del taller de dibujo y pintura; por otro, llevó a cabo numerosos encargos pictóricos para satisfacer la demanda del centro, tal es así que "dicho Colegio está lleno de cuadros míos", reconocía con cierto orgullo en una carta dirigida al Obispo de Madrid-Alcalá Prudencio Melo en $1919^{29}$.

ilustraciones en numerosas revistas. En 1912 publicó Mnemotecnografía, libro sobre la importancia del arte gráfico en el desarrollo de la memoria. A todo ello unió su vocación docente que desarrolló en Graus, Huesca y Guadalajara. Fue académico de San Fernando. ARA TORRALBA, Juan Carlos: "Sinfonías legendarias en tono menor: La Campana de Huesca (1893-1895), glorias y miserias de la primera y postergada revista ilustrada de la provincia", Alazet, 7, 1995, p. 36; GARCÍA GUATAS, Manuel: "Graus y su escuela de artes y oficios", Somontano, 6, 1996-1997, pp. 124-129. AMNP (Archivo del Museo Nacional del Prado). Sign. L3. Libro de copistas, 1887-1895.

${ }_{25}$ De la presencia de Ros Ráfales en Lekaroz da noticia La Avalancha, no 30, 8-71896, p. 68.

26 AHPCP. FCL. Crónica del P. Berardo de Cieza. Letra “E” (años 1904-1905), 9-021905, f. 42v.

27 AHPCP. FCL. Religiosos particulares desde 1902. Cartas de Pedro M. de Madrid al Min. Prov. Antonio de Iroz, Lekaroz, 4-9-1909, y San Sebastián, 3-9-1910.

${ }^{28}$ Santiago Arcos y Ugalde (Santiago de Chile, 1852-San Sebastián, 1912) fue un pintor formado en Madrid y París, donde acudió a l'École des Beaux Arts y fue discípulo de Léon Bonnat y de Raimundo de Madrazo. Su actividad profesional discurre a caballo entre París y Madrid, participando en el Salon y en las Exposiciones Nacionales de Bellas Artes, obteniendo medallas y menciones honoríficas. Tras su expulsión de Francia en 1906 se establece en Hernani y San Sebastián, ciudad en la que abrió un estudio. Cultivó prácticamente todos los géneros, si bien destaca en su faceta de retratista y pintor costumbrista. AlCOLEA ALBERO, Fernando: Pintores extranjeros en España. Santiago Arcos y Ugalde, 2013 www.fernandoalcolea.com/Pintores-extranjeros-en-Espanya/Santiago-deArcos-y-Ugalde/ Consultado el 29-10-2014. Por circunstancias familiares, en la primera década del siglo XX Arcos estableció relación con el Colegio de Lekaroz, al que regaló un Ecce Homo en 1906.

${ }^{29}$ AHDM. Caja sign. 24646/42. Expediente de D. Pedro Satué. Carta de Fr. Pedro de Madrid dirigida al Sr. Obispo de Madrid-Alcalá. Tudela, 16-6-1919. 


\section{PRODUCCIÓN PICTÓRICA: RETRATO, PAISAJE Y COPIAS}

Dentro de la producción pictórica de Fr. Pedro de Madrid, el retrato fue una de sus principales ocupaciones, como certifican los del Papa Pío X, del P. General de los Capuchinos Fr. Bernardo de Andermatt, y del fundador de Lekaroz P. Llevaneras, realizados durante su estancia madrileña en 1904-1905; su envío acompañado de instrucciones precisas acerca del lugar que deben ocupar en función de la iluminación de las salas, nos habla de un artista cuidadoso hasta en los mínimos detalles. Pintados a partir de una fotografía ${ }^{30}$, su rigidez compositiva se atempera merced al empleo de una pincelada suelta y fluida, patente sobre todo en algunos detalles de la indumentaria.

Cultivó asimismo el paisaje al aire libre, como testimonia una fotografía (Figura 3) en la que aparece frente al caballete en plena naturaleza, paleta y pincel en mano, con la caja de pinturas a sus pies; sentado con el rostro vuelto hacia el espectador, plasma el puente medieval de Reparacea en Oieregi, en el inmediato valle de Bertizarana, motivo que captó el interés de otros paisajistas navarros contemporáneos ${ }^{31}$. Conservamos una Vista del Colegio de Lekaroz contemplado desde la huerta ( $58 \times$ 98), óleo sobre tabla realizado hacia 1910 desde una amplia perspectiva y con un punto de vista elevado que permite diferenciar un esquema compositivo tripartito perceptible en otros pintores de la época como Darío de Regoyos.

Sin embargo, la mayor parte de su pintura está configurada por copias destinadas a las dependencias del Colegio de Lekaroz. No resulta nada desdeñable su personalidad como copista, en una época en la que esta profesión comienza a merecer el reconocimiento de diversos sectores sociales ${ }^{32}$; de hecho, buena parte de sus estancias fuera de Lekaroz tienen por objeto abastecer al Colegio de pinturas religiosas localizadas en diversos museos españoles.

Al inicio del curso 1906-1907 viaja a Madrid a realizar copias del Museo del Prado, cometido que volverá a repetir en el otoño de 1912, permaneciendo en esta

${ }^{30}$ Así podemos certificarlo en el caso del P. Llevaneras: "Por el conducto de Fr. Miguel de Tudela, le mando a Fr. Pedro de Madrid la fotografía del Rmdo. P. Joaquín de Llevaneras para el cuadro al óleo". AHPCP. FCL. Crónica del P. Berardo de Cieza. Letra "E" (años 1904-1905), 10-1-1905, f. 30.

${ }^{31}$ MURUZẢBAL, José María: Basiano. El pintor de Navarra. Pamplona, 1989, p. 247.

${ }^{32}$ Aunque algo más tardías, sirvan, a modo de ejemplo, las reseñas de HESPERIA: "De arte: un recuerdo sentimental para la labor inadvertida y silenciosa del artista copista", Alrededor del mundo, n 1574, 17-8-1929, p. 920; VALVERDE, Salvador: "Los copistas del Museo del Prado", Crónica, 7-6-1931, s.p.; y FORNET, Emilio: "Copistas en el Prado", Estampa, n 325, 31-3-1934, s.p. En un sentido más amplio, aporta datos de interés REYERO HERMOSILLA, Carlos: Observadores: estudiosos, aficionados y turistas dentro del cuadro. Barcelona, 2008, pp. 174-177. 
ocasión por espacio de tres años. Testimonio de su labor es la instancia firmada con su nombre civil, Pedro Satué, que dirige el 14 de enero de 1913 al director de la pinacoteca, el pintor sevillano José Villegas Cordero, solicitando permiso para "hacer estudios de las obras de arte que encierra el Museo de su digna dirección". Requisito imprescindible para lograr la autorización era contar con el aval de una persona ligada al Museo; en este caso fue el restaurador Federico Amutio ${ }^{33}$, quien consideraba al interesado "con suficiente aptitud y digno de obtener el favor que solicita". De nuevo figura inscrito en el registro de copistas el 28 de noviembre de 1914, revelador de que en tal fecha continuaba desarrollando su labor pictórica en la capital ${ }^{34}$.

En el verano de 1915 finaliza su estancia madrileña y regresa a Lekaroz, si bien a finales de año marcha a tierras andaluzas "con objeto de copiar para este Colegio algunos cuadros de pintores célebres", refiere el rector Fr. Joaquín M ${ }^{\mathrm{a}} \mathrm{de}$ Beriain $^{35}$. En 1916 reside en Córdoba, ocupado en copiar obras de su Museo de Bellas Artes procedentes del desamortizado convento capuchino del Santo Ángel Custodio, para cuya labor recibe lienzos y otros materiales enviados desde el establecimiento de Daniel Valdés en la sevillana calle de Tetuán ${ }^{36}$; en julio el contador de Lekaroz le remite 350 pesetas para hacer frente a los gastos ${ }^{37}$.

Al año siguiente se traslada a Sevilla, donde permanecerá hasta el verano de 1918 realizando copias de cuadros de Murillo depositados en su Museo de Bellas Artes $^{38}$. Conviene recordar al respecto que su estancia sevillana coincide con el III

${ }^{33}$ Federico Amutio y Amil (Madrid, 1869-1942) se formó en la Escuela de Arquitectura de Madrid y en la Academia de Bellas Artes de San Fernando, con Carlos Luis Ribera y Luis de Madrazo; fue yerno del también pintor Luis Álvarez Catalá, con quien colaboró en su taller. Concurrió a certámenes como la Nacional de Bellas Artes, alzándose con terceras medallas en 1890 y 1892. En 1902 fue nombrado Restaurador-Dorador del Museo del Prado, y en 1918 Restaurador-Forrador. En 1931 Alfonso XIII le concedió la Encomienda de la Orden Civil de Alfonso XII. PANTORBA, Bernardino: Historia y crítica de las Exposiciones de Bellas Artes celebradas en España. Madrid, 1948, pp. 128, 138, 171 y 337; GONZÁLEZ, Carlos y MARTÍ, Montse: Pintores españoles en Roma (1830-1900). Barcelona, 1996, p. 50.

${ }^{34}$ AMNP. Caja 1377, leg. 1486, exp. 1; Sign. L35. Registro de copistas 1906-1914; Sign. L40. Registro de copistas 1914-1918. Mi agradecimiento a Ana Martín Bravo y a Yolanda Cardito por la información facilitada.

${ }^{35}$ AIPV (Archivo de la Institución Príncipe de Viana). Leg. 2/25. Año 1917. Carta del P. Rector del Colegio de Lecároz, 19-2-1917.

${ }^{36}$ El 18 de enero de 1916, Daniel Valdés responde a una carta de Fr. Pedro de Madrid fechada el 2 de enero, anunciándole el envío de materiales y la subida de precios a causa de la guerra. AHPCP. FCL. Cartas 1912-1917.

37 AHPCP. FCL. Libro 1-1916. "Pedro de Madrid, su estancia pintando en Córdoba: 350 ptas".

${ }^{38}$ Por desgracia, la consulta acerca de posible información relacionada con Fr. Pedro de Madrid en los fondos documentales del Museo de Bellas Artes y de la Academia 
Centenario del nacimiento del pintor, si bien la efeméride no dio lugar a grandes celebraciones $^{39}$. Con todo, desde comienzos de siglo se había iniciado el proceso de revalorización del artista, tanto con la creación en 1903 de la Sala Murillo en el Museo de Bellas Artes y su posterior reorganización en 1914-1915 ${ }^{40}$, como con la aparición de artículos de prensa ${ }^{41}$ y la publicación en 1913 de una monografía a cargo de August L. Mayer ${ }^{42}$, despojada de todo exceso laudatorio pero sin rebajar su mérito ${ }^{43}$.

\section{FR. PEDRO DE MADRID COPISTA: RIBERA, ZURBARÁN Y MURILLO}

La labor de Fr. Pedro de Madrid como copista se traduce en un conjunto de lienzos recogidos en los inventarios de Lekaroz ${ }^{44}$ que lo enfrentan a los grandes maestros del Siglo de Oro español. Es el caso de un San Pablo Ermitaño (104,5 x 85) (Figura 4) a partir del original de José de Ribera (h. 1637, Museo Nacional del Prado), donde la figura del santo, en profunda meditación y acto de penitencia, es tratada con un intenso tenebrismo de raigambre caravaggesca, deteniéndose en detalles como la huesuda anatomía o las arrugas de la piel ${ }^{45}$. Trata el capuchino de acercarse al pintor valenciano en el manejo de la luz con la que modela el consumido cuerpo del eremita, si bien carece de la vigorosidad del original y del plástico tratamiento de detalles como el cabello y barbas y el bodegón de vanitas.

de Bellas Artes de Santa Isabel de Hungría, no ha dado resultados positivos. Quiero manifestar mi gratitud a Ignacio Hermoso Romero, Conservador del Museo de Bellas Artes de Sevilla, a Fernando Fernández Gómez, Secretario General de la Real Academia de Santa Isabel, y a Margarita Toscano Gil, por la amabilidad con que atendieron mi petición.

39 En enero de 1918, lamentaba Silvio Lago (pseudónimo del periodista y crítico de arte José Francés) que "el aniversario del tercer centenario del nacimiento de Murillo ha pasado en España inadvertido". LAGO, Silvio: "El Centenario de un gran pintor español. Bartolomé Esteban Murillo", La Esfera, n 212, 19-1-1918, s. p. Hubo no obstante iniciativas puntuales como la especial atención que le dedicó dicho revista en el mismo número que recogía el anterior comentario.

${ }^{40}$ RODRÍGUEZ AGUILAR, Inmaculada Concepción: Arte y cultura en la prensa. La pintura sevillana (1900-1936). Sevilla, 2000, pp. 76-78.

${ }^{41}$ Sirva, a modo de ejemplo, el de PINO, Cándido del: "Notas de Arte", El Noticiero Sevillano, 1-6-1909, encomiástico tanto de la pintura de Murillo como de la labor del Museo de Bellas Artes en su recuperación.

42 MAYER, Ausgust L.: Murillo: Des Meisters Gemälde. Stuttgart und Berlin, 1913.

${ }^{43}$ VALDIVIESO, Enrique: Murillo. Catálogo razonado de pinturas. Madrid, 2010, p. 45.

${ }^{44}$ El más completo es la Relación de obras de arte existentes en el Convento de Padres Capuchinos de Lecároz (Navarra). Lecároz, enero 1996, elaborado por Francisco Javier Cabodevilla. AHPCP. FCL.

45 PÉREZ SÁNCHEZ, Alfonso E.: "San Pablo ermitaño", en Ribera, 1591-1652. Madrid, 1992, pp. 296-297. 
Los registros lecarocenses citan también como copia de Ribera un San Bartolomé (158 x 106) (Figura 5). En posición sedente y envuelto en una amplia capa roja, sostiene en su mano izquierda el atributo del cuchillo, en tanto que con la derecha señala la escena de su martirio que se desarrolla al fondo; junto a la monumental figura reposan los fragmentos de una estatua pagana, alusivos a las divinidades romanas que se negó a adorar y que se rompían ante su presencia. Con todo, la circunstancia de que se trate del único lienzo que lleva la firma autógrafa de Fr. Pedro, unida al hecho de que no hayamos identificado el original en la producción pictórica ni grabada del pintor valenciano, nos hace preguntarnos si no estaremos ante una obra propia. Sea como fuere, su ejecución queda justificada por tratarse del titular de la parroquia de Lekaroz, localidad baztanesa que acogía al centro capuchino.

Fr. Pedro copió igualmente un San Francisco en meditación (h. 1658-1660) de Zurbarán que los inventarios identifican con el custodiado en la Alte Pinakothek de Munich, en el que el pintor extremeño muestra al asceta consumido en éxtasis a través de la posición de las manos apoyadas en el pecho y en una calavera, y del gesto del rostro de boca abierta y ojos alzados ${ }^{46}$. Desconocemos el paradero actual de esta copia.

Sin embargo, en su aproximación a los grandes maestros del Seiscientos, Fr. Pedro de Madrid se revela como un excelente intérprete de Murillo, del que traduce con virtuosismo su estilo vaporoso, la pincelada de factura deshecha y el vibrante manejo de la luz, a la vez que mantiene la atmósfera de misticismo que impregna la obra del pintor sevillano. Tenemos constancia documental de nueve lienzos murillescos copiados por el capuchino, la mayoría durante su etapa sevillana de 1917-18. Se trata de San Francisco abrazando a Cristo, las dos versiones de San Antonio de Padua y el Niño, y La Virgen de la servilleta, pintados entre 1666 y 1669 con destino al convento e iglesia de capuchinos de Sevilla, a los que se suma la Inmaculada Concepción encargada por los franciscanos en torno a 1650, todos ellos depositados en el Museo de Bellas Artes. Fr. Pedro copió también Los Niños de la concha (h. 1670-1675, Museo Nacional del Prado), y Santo Tomás de Villanueva niño repartiendo su ropa entre los pobres (h. 1665-1670, Art Museum de Cincinnati), que Murillo realizó para el convento de San Agustín ${ }^{47}$. Los inventarios recogen otras dos copias cuyo paradero ignoramos: un San Juan Bautista (¿quizás homónimo del destinado al retablo mayor de capuchinos de Sevilla?) y una "tablita redonda" de la que no se especifica su asunto.

46 DELENDA, Odile: Francisco de Zurbarán, 1598-1664. Catálogo razonado y crítico. Madrid, 2009, pp. 709-710.

47 Acerca del recorrido y vicisitudes de este lienzo, véase DE ROSE VIEJO, Isadora: "Desde el palacio madrileño de Godoy al mundo entero", en El arte español fuera de España. Madrid, 2003, pp. 320-322. 
Una vez en Lekaroz, las copias de Fr. Pedro de Madrid ocuparon distintas dependencias, según recogen inventarios y plasman fotografías. Sin embargo, el cierre del convento en 2003 (el Colegio ya lo había hecho en 1990) obligó al traslado de su patrimonio artístico a los conventos de Pamplona y Sangüesa.

La iglesia de San Antonio de Pamplona custodia tres copias de Murillo que, por su calidad, constituyen las de mayor mérito artístico de todo el conjunto. Dos de ellas se ajustan al tamaño del original. Es el caso de San Francisco abrazando a Cristo (292 x 181) (Figura 6), episodio que no figura en las biografías oficiales de san Francisco, si bien existe un referente textual del mismo en la Leyenda de la beata Cristina de Saint-Truiden, beguina flamenca fallecida en 1224, y protagoniza igualmente estampas devocionales flamencas. Se trata de un tema significativo en la iconografía franciscana, por cuanto aúna la visión del fundador de la orden con la profunda devoción a Cristo crucificado que profesaban los capu$\operatorname{chinos}^{48}$. Fr. Pedro sigue fielmente la composición original, que muestra al Crucificado desclavando su brazo derecho de la cruz para acoger bajo su regazo al franciscano, quien de pie y con el rostro invadido por el misticismo, abraza al Redentor. El gesto de Cristo es expresión de la recompensa divina a la renuncia del santo a los bienes terrenales para servir a Dios y al prójimo, explicitada en su actitud de pisar el globo terráqueo, así como en el texto del libro que sostienen dos ángeles niños, alusivo al pasaje de Lucas 14, 33: Qui non renuntiat omnibus, quae possidet, non potest meus esse discipulus. La intensidad lumínica contribuye a resaltar las figuras del Crucificado y san Francisco, que se recortan sobre un paisaje urbano apenas esbozado ${ }^{49}$.

Tambien mantiene las medidas del original el San Antonio de Padua con el Niño (283 x 188) (Figura 7), tema iconográfico de honda devoción popular basado en un episodio de su vida recogido en el Liber Miraculorum. En medio de un paisaje se hace presente el santo de rostro juvenil, arrodillado ante el Niño en señal de rendida devoción y con el cuerpo en escorzo, levemente inclinado hacia adelante; viste hábito franciscano y porta en su mano derecha el ramo de azucenas como símbolo de su virginidad, en tanto que con la izquierda abraza al pequeño, sentado sobre el libro de la Sagrada Escritura que actúa como pedestal. En el espacio superior apreciamos un rompimiento de gloria con un grupo de ángeles que contempla el trascendental abrazo, desde los cuales desciende una cascada de luz que sirve de fondo a la figura del Niño, destacándose así de la

${ }^{48}$ SÁNCHEZ MILLÁN, Rafael: "La popularidad de los tipos iconográficos. Cristo crucificado abrazando desde la cruz: ¿imagen cristológica, bernardina o franciscana?”, en Congreso Internacional Imagen y Apariencia. Murcia, 2009. http://congresos.um.es/imagenyapariencia/imagenyapariencia2008/paper/view/1181/1151. Consultado el 4-11-2014.

${ }_{49}$ ANGULO ÍÑIGUEZ, Diego: Murillo, Madrid, 1981, T. I, pp. 367-369, T. II, pp. 71-72, T. III, láms. 246-247; VALDIVIESO, Enrique: Murillo..., op. cit., pp. 142-143 y 398. 
penumbra del resto del lienzo, dominado por una atmósfera afectiva merced a los rostros y gestos de ambos personajes ${ }^{50}$.

La tercera copia del templo pamplonés es una Inmaculada Concepción ( $286 \mathrm{x}$ 190) (Figura 8) realizada por Murillo para la iglesia sevillana de San Francisco, que proponemos ahora como obra de Fr. Pedro de Madrid ${ }^{51}$. No podía faltar el tema murillesco por excelencia, máxime cuando el capuchino tuvo oportunidad de asistir a la exposición del Palacio Arzobispal conmemorativa del III Centenario del voto concepcionista de la ciudad ( 8 de diciembre de 1917) en la que se exhibieron obras de importantes artistas, entre ellas la Purísima de la Sala Capitular de la Catedral hispalense ${ }^{52}$. En esta ocasión se aparta de las medidas del original (436 x 292), justificadas por su emplazamiento a gran altura -de ahí el sobrenombre de La Grande o La Colosal-, y opta por mantener el formato de los dos lienzos anteriores, como si los tres hubiesen sido concebidos con criterio uniforme para un mismo ámbito del Colegio de Lekaroz. En su representación inmaculista más temprana, Murillo desarrolla una obra monumental cuya lejana contemplación en contrapicado provoca ciertos desajustes en su visión frontal, como la mirada baja de María; así se constata en el lienzo pamplonés, dispuesto en el presbiterio prácticamente a la altura del espectador. Apartándose de la verticalidad y rigidez de las anteriores Inmaculadas sevillanas, la de Murillo aparece imbuida del espíritu apoteósico propio del barroco, a la vez que incorpora novedades iconográficas: la Virgen viste túnica blanca y manto azul conforme a la visión de la beata Beatriz de Silva en el siglo XVI, y aparece sobre un globo lunar, con la

${ }^{50}$ ANGULO ÍÑIGUEZ, Diego: Murillo..., op. cit., T. I, pp. 366-367, T. II, p. 73, T. III, láms. 251-252; Valdivieso, pp. 141-142 y 400.

${ }^{51}$ Existe cierta confusión acerca del origen de este lienzo, que M. C. García Gainza relaciona con una copia de la Inmaculada de Ribera integrante del legado que en 1891 ingresó en el Colegio de Lekaroz procedente de la Real Academia de San Fernando, si bien corrige la autoría y lo identifica con la Concepción de Murillo. GARCÍA GAINZA, María Concepción: "Pinturas de la Real Academia en el Colegio de Capuchinos de Lecároz", Academia. Boletín de la Real Academia de Bellas Artes de San Fernando, 94-95, 2002, pp. 9-22. Teniendo en cuenta el autor, la diferencia de tamaño (206 x 142 el de la Academia, 286 x 190 el de capuchinos) y la ausencia de número de registro, así como el hecho de que los inventarios lecarocenses recogen una copia de la Inmaculada de Murillo realizada por Fr. Pedro de Madrid, planteamos la hipótesis de que estemos ante dos lienzos distintos, y que el de capuchinos de Pamplona se corresponda en realidad con este último, cuyas medidas, materiales y ejecución formal guardan unidad con los de san Francisco y san Antonio de Padua. De estar en lo cierto, ignoramos el paradero de la copia de Ribera procedente de la Academia.

${ }^{52}$ RODRÍGUEZ AGUILAR, Inmaculada Concepción: Arte y cultura en la prensa..., op. cit., p. 318. 
rodilla apoyada en una nube que impulsa un grupo de ángeles en movimiento ascendente, en medio de un rompimiento de gloria de cálidas tonalidades ${ }^{53}$.

Los restantes lienzos de Fr. Pedro de Madrid que copian originales de $\mathrm{Mu}-$ rillo se conservan en el convento capuchino de Sangüesa. En la portería queda Los niños de la concha (80 x 102) (Figura 9), en el que a partir de un grabado de Guido Reni inspirado a su vez en Annibale Carracci, el pintor sevillano otorga un significado trascendental al tema infantil tan habitual en su producción, transformándolo en una prefiguración del Bautismo de Cristo en el Jordán ${ }^{54}$. Los tres últimos están almacenados en el desván, ajenos a cualquier medida de conservación, de manera que reclaman una limpieza y restauración urgentes (Figura 10). Uno de ellos es La Virgen de la servilleta (67 x 70), en el que Madre e Hijo contemplaban a los propios capuchinos de Sevilla, dada su ubicación en el refectorio conventual ${ }^{55}$. El segundo, San Antonio de Padua con el Niño (192 x 120), es versión del destinado al retablo mayor de la iglesia capuchina, donde vuelven a repetirse los gestos de intensa espiritualidad en el abrazo del santo a Jesús ${ }^{56}$. Finalmente, Santo Tomás de Villanueva niño repartiendo su ropa entre los pobres (165 x 143) subraya su vocación limosnera desde su infancia, concebido como una escena de género protagonizada por pícaros que tanta popularidad proporcionaron al pintor. La copia de Fr. Pedro difiere ligeramente del original al adoptar un formato más cuadrado que elimina la parte superior, si bien mantiene el escenario en plena calle de edificios humildes donde el santo niño se despoja de sus ropas con las que se apresuran a vestir los muchachos, dando lugar a una rica galería de expresiones infantiles ${ }^{57}$.

${ }^{53}$ ANGULO ÍÑIGUEZ, Diego: Murillo..., op. cit., T. I, pp. 311-313, T. II, pp. 126127, T. III, láms. 97 y 98; VALDIVIESO, Enrique: Murillo..., op. cit., pp. 210-211 y 300.

${ }^{54}$ ANGULO ÍÑIGUEZ, Diego: Murillo..., op. cit., T. I, p. 440, T. II, p. 199, T. III, lám. 411; VALDIVIESO, Enrique: Murillo..., op. cit., pp. 165-166 y 491.

${ }_{55}$ ANGUlO ÍÑIGUEZ, Diego: Murillo..., op. cit., T. I, p. 375, T. II, pp. 66-67, T. III, lám. 242; VALDIVIESO, Enrique: Murillo..., op. cit., pp. 145-147 y 394.

${ }^{56}$ ANGULO ÍNIIGUEZ, Diego: Murillo..., op. cit., T. I, p. 365, T. II, p. 64, T. III, lám. 232; VALDIVIESO, Enrique: Murillo..., op. cit., pp. 140 y 390.

57 ANGULO ÍNIIGUEZ, Diego: Murillo..., op. cit., T. I, pp. 318-319, T. II, pp. 55-56, T. III, láms. 221-223; MARTÍN GONZÁLEZ, Juan José: "Murillo ante la estadística", Goya, 169-171, 1982, p. 25; VALDIVIESO, Enrique: Murillo..., op. cit., pp. 131 y 387. Quizás Fr. Pedro de Madrid conociera la obra a través de estampas, como la abierta en 1785 por Diego de San Román y Codina. CARRETE PARRONDO, Juan: "El grabado de reproducción. Murillo en las estampas españolas”, Goya, 169-171, 1982, p. 147. 


\section{CONCLUSIÓN}

"Hábil copista de cuadros de Murillo". Así definía, con conocimiento de causa, el P. Eulogio Zudaire a Fr. Pedro de Madrid ${ }^{58}$; y así lo certifica el conjunto de lienzos que copió en Sevilla y Madrid con destino al Colegio de Lekaroz, depositados actualmente en Pamplona y Sangüesa. La proximidad del IV Centenario del nacimiento del pintor sevillano constituye la ocasión propicia para dar a conocer este legado que contribuye a ampliar su extenso catálogo de copias.

Músico, fotógrafo, pintor, la polifacética personalidad artística del capuchino fray Pedro de Madrid se revela atractiva no solo por su contacto con artistas y museos, sino por su posterior trayectoria fotográfica con estudio abierto en Madrid y su vinculación al mundo del teatro y el espectáculo.

Fecha de recepción: 8 de abril de 2015.

Fecha de aceptación: 20 de noviembre de 2015.

${ }^{58}$ ZUDAIRE HUARTE, Eulogio: Lekaroz..., op. cit., p. 102. 
LA ESFERA

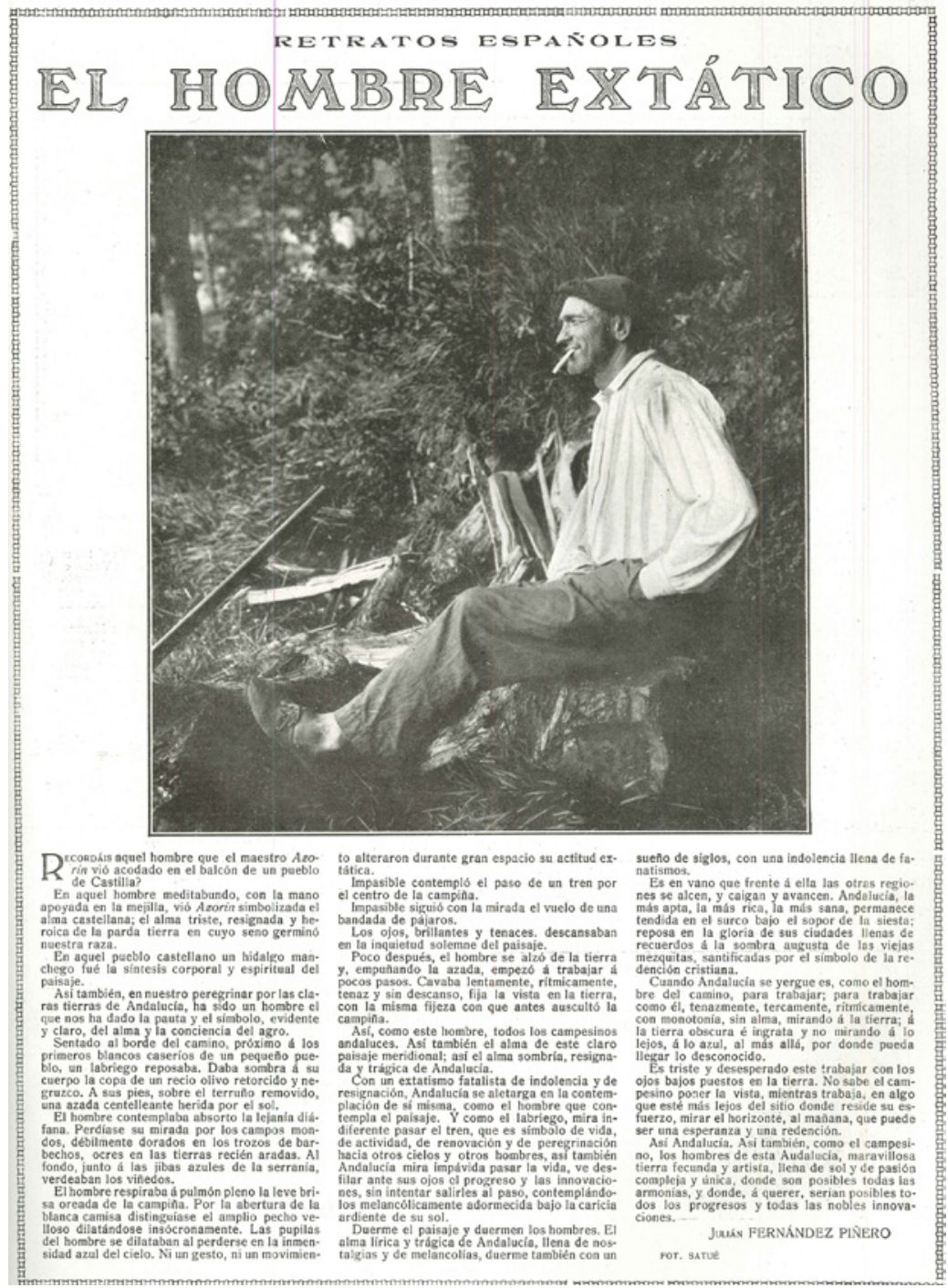

Figura 1. Campesino baztanés. Pedro Satué. La Esfera, 28 de agosto de 1920. 


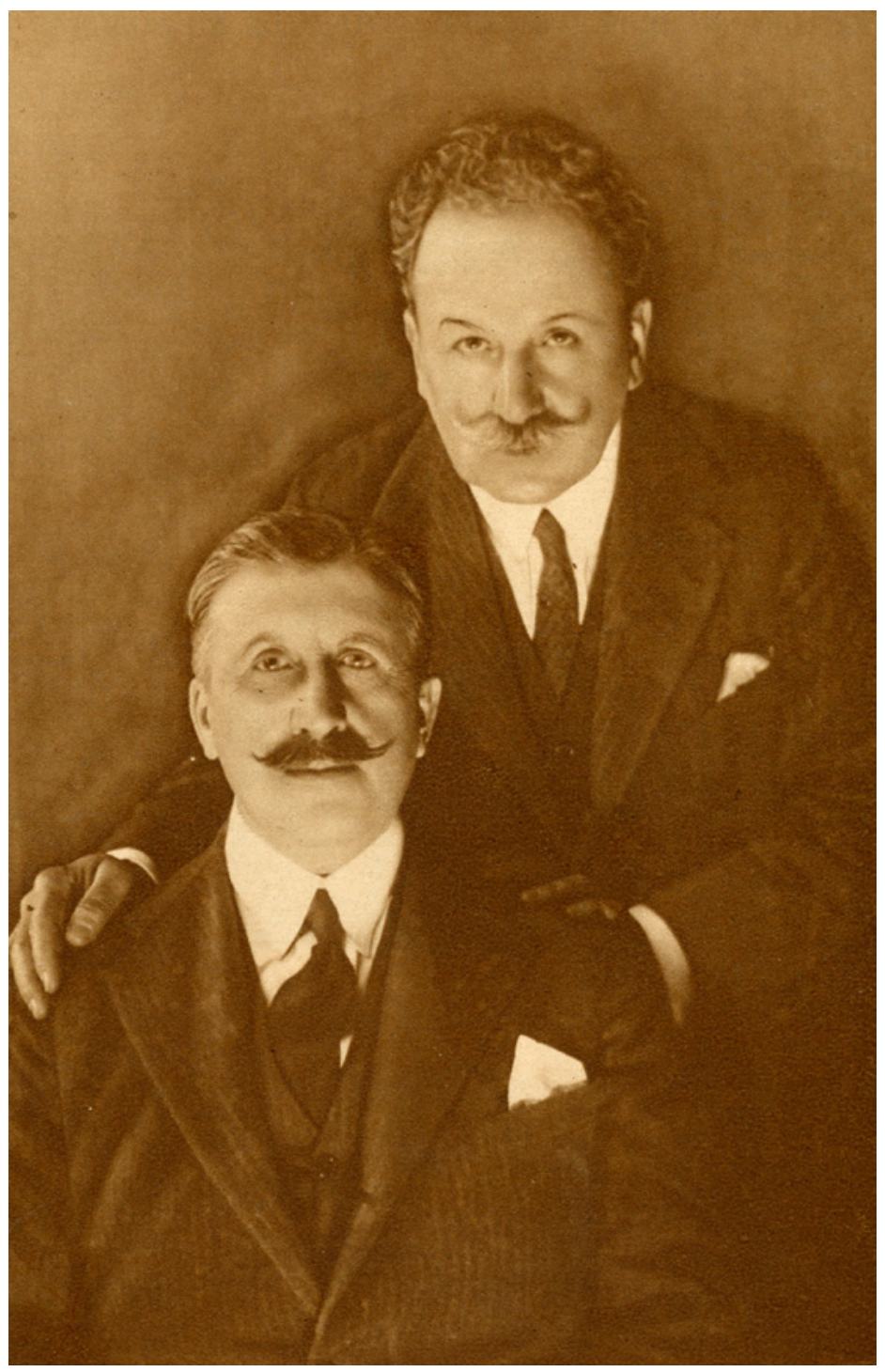

Figura 2. Retrato de los hermanos Álvarez Quintero. Foto Antsa (Pedro Satué). Estampa, 7 de febrero de 1928. 


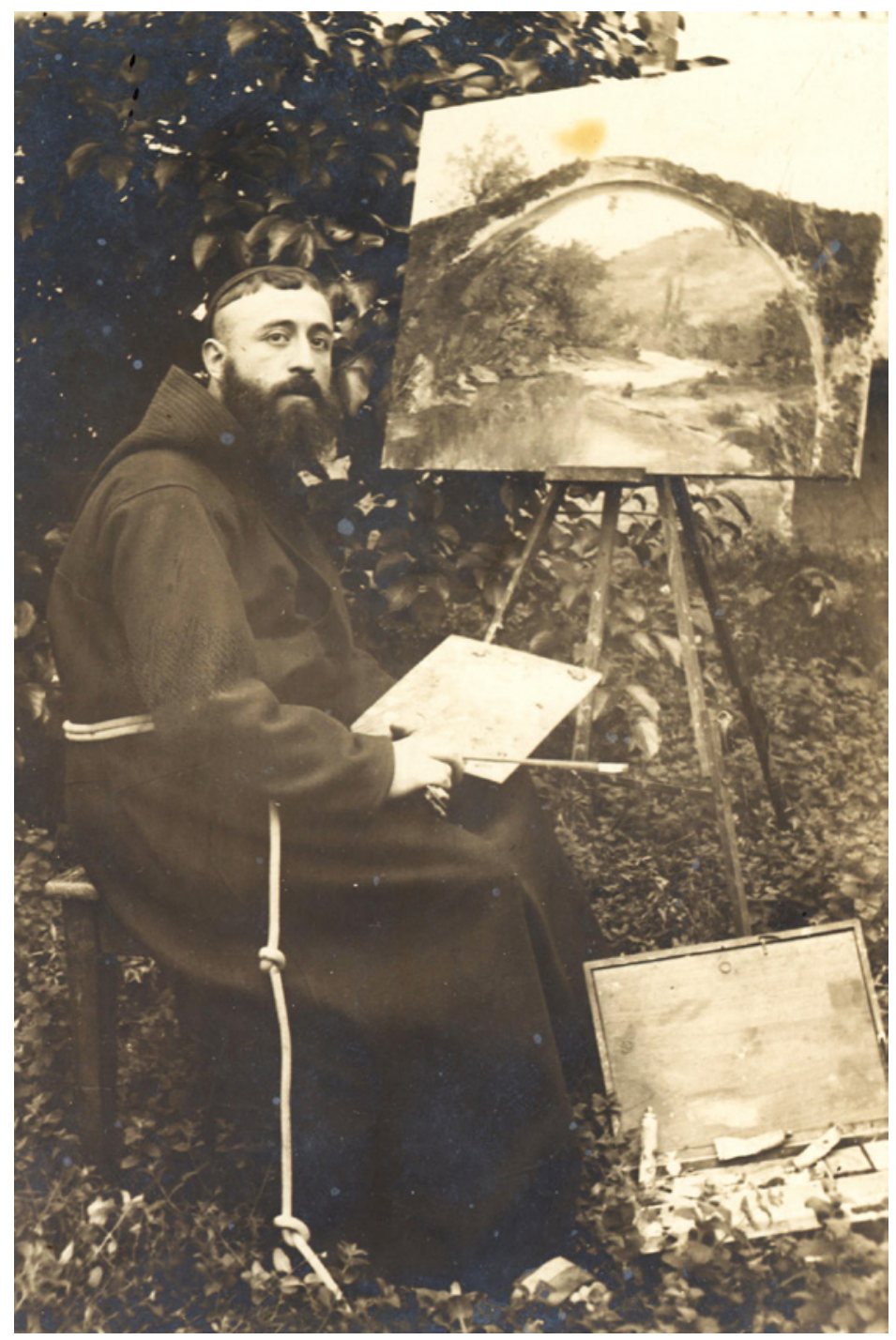

Figura 3. Fray Pedro de Madrid pintando el puente de Reparacea (Bertizarana, Navarra). Hacia 1910. Archivo Histórico-Provincial de Capuchinos de Pamplona. 


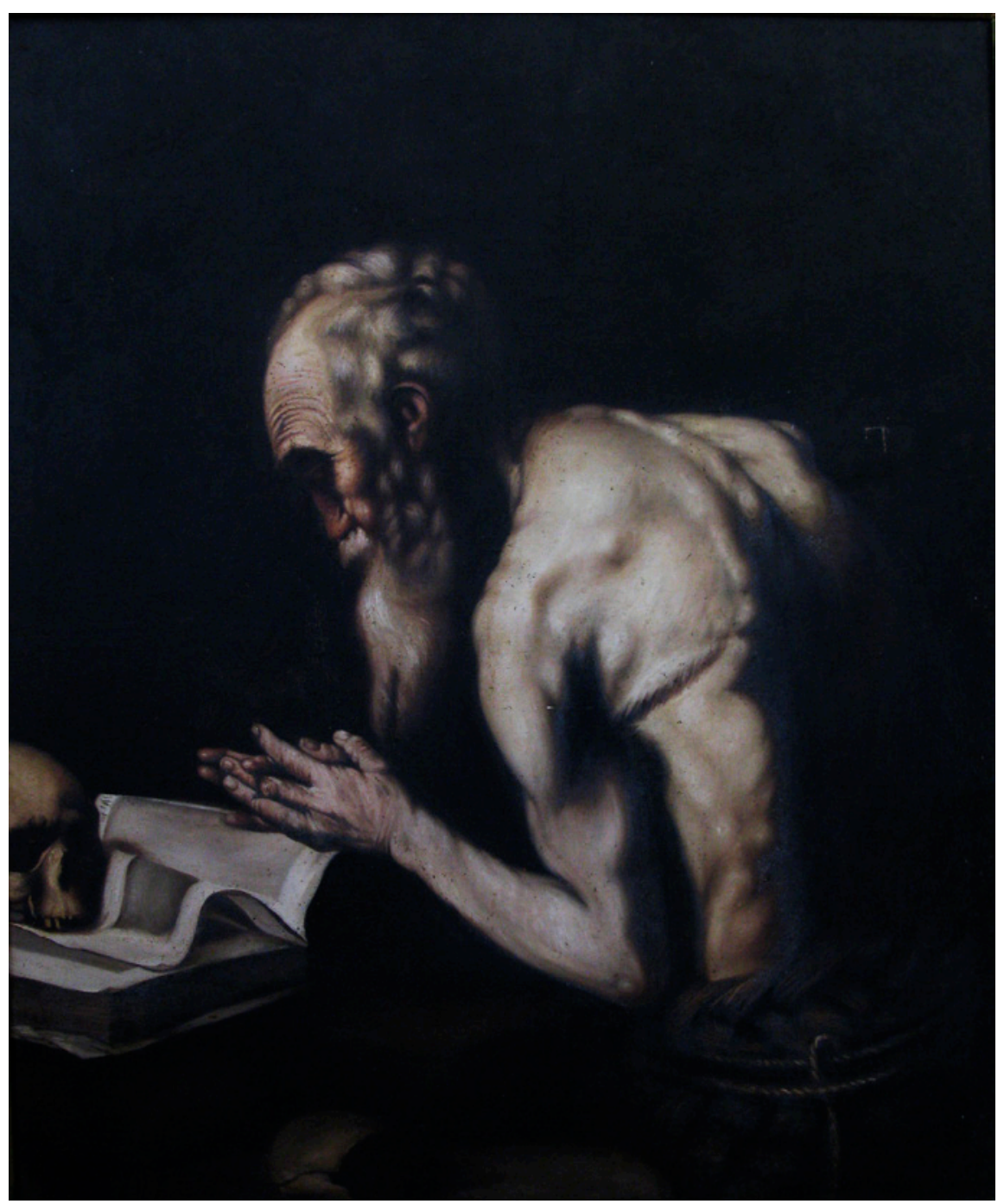

Figura 4. San Pablo ermitaño. Fray Pedro de Madrid. 1912-1914. Convento de capuchinos de Sangüesa (Navarra). 


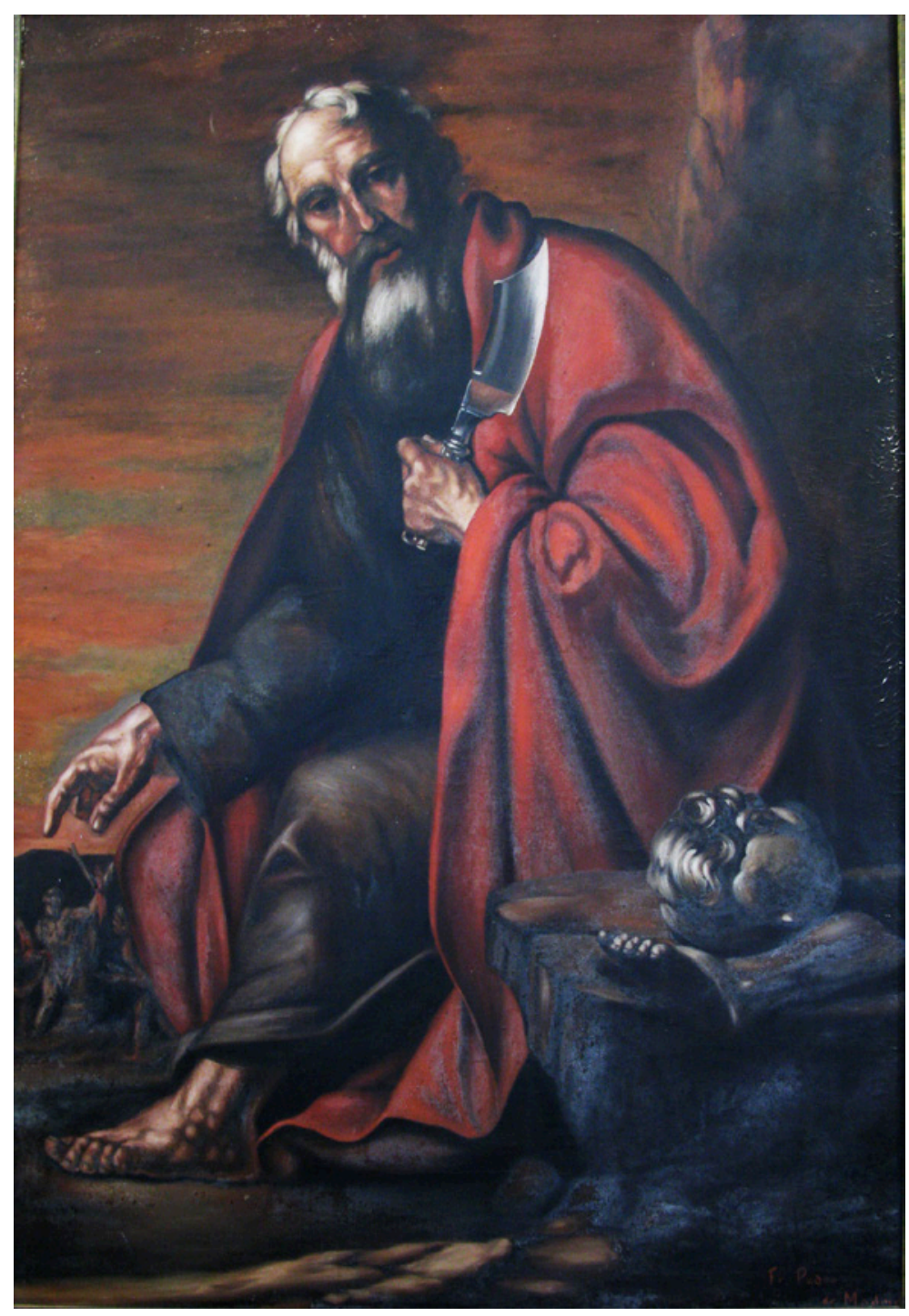

Figura 5. San Bartolomé. Fray Pedro de Madrid. Hacia 1915. Convento de capuchinos de Sangüesa (Navarra). 


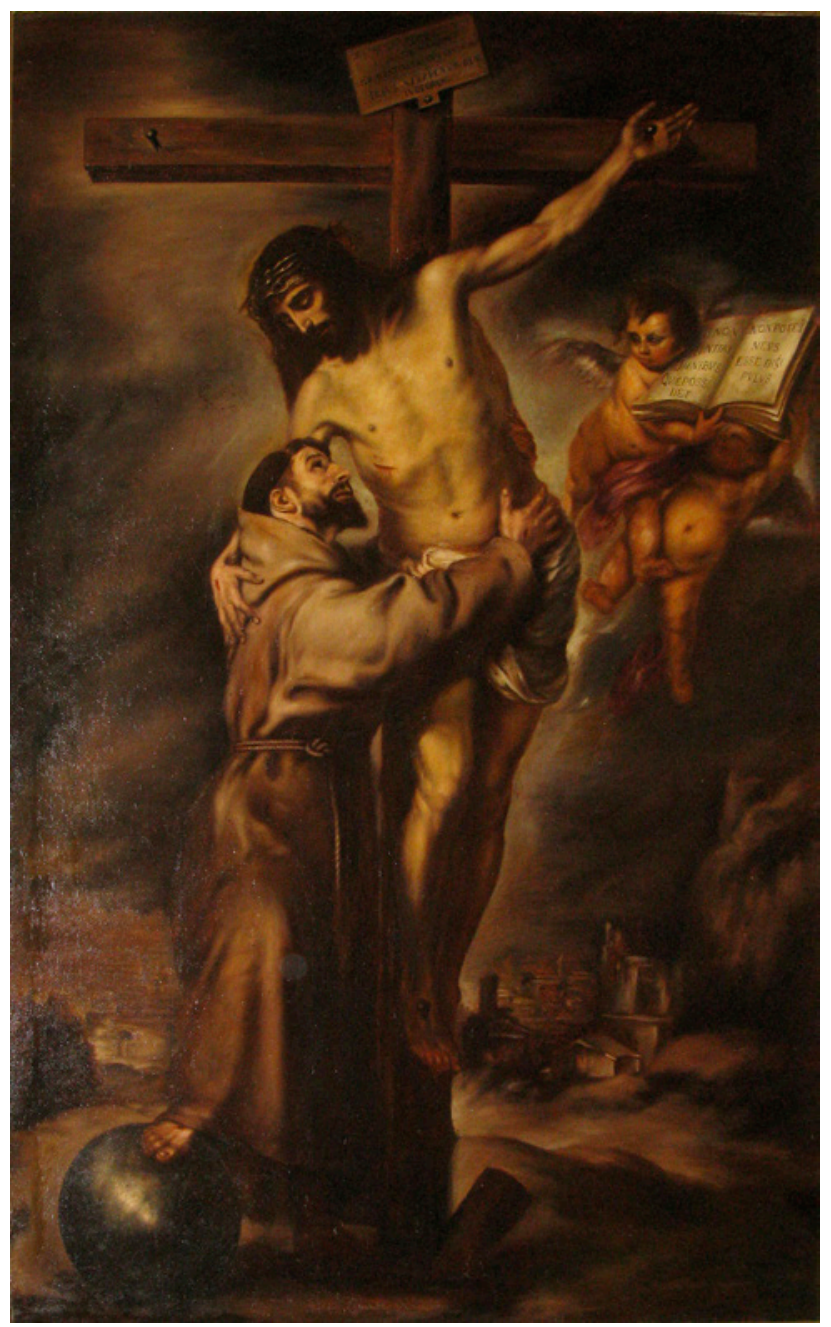

Figura 6. San Francisco abrazando a Cristo. Fray Pedro de Madrid. 1917-1918. Iglesia de San Antonio de Pamplona. 


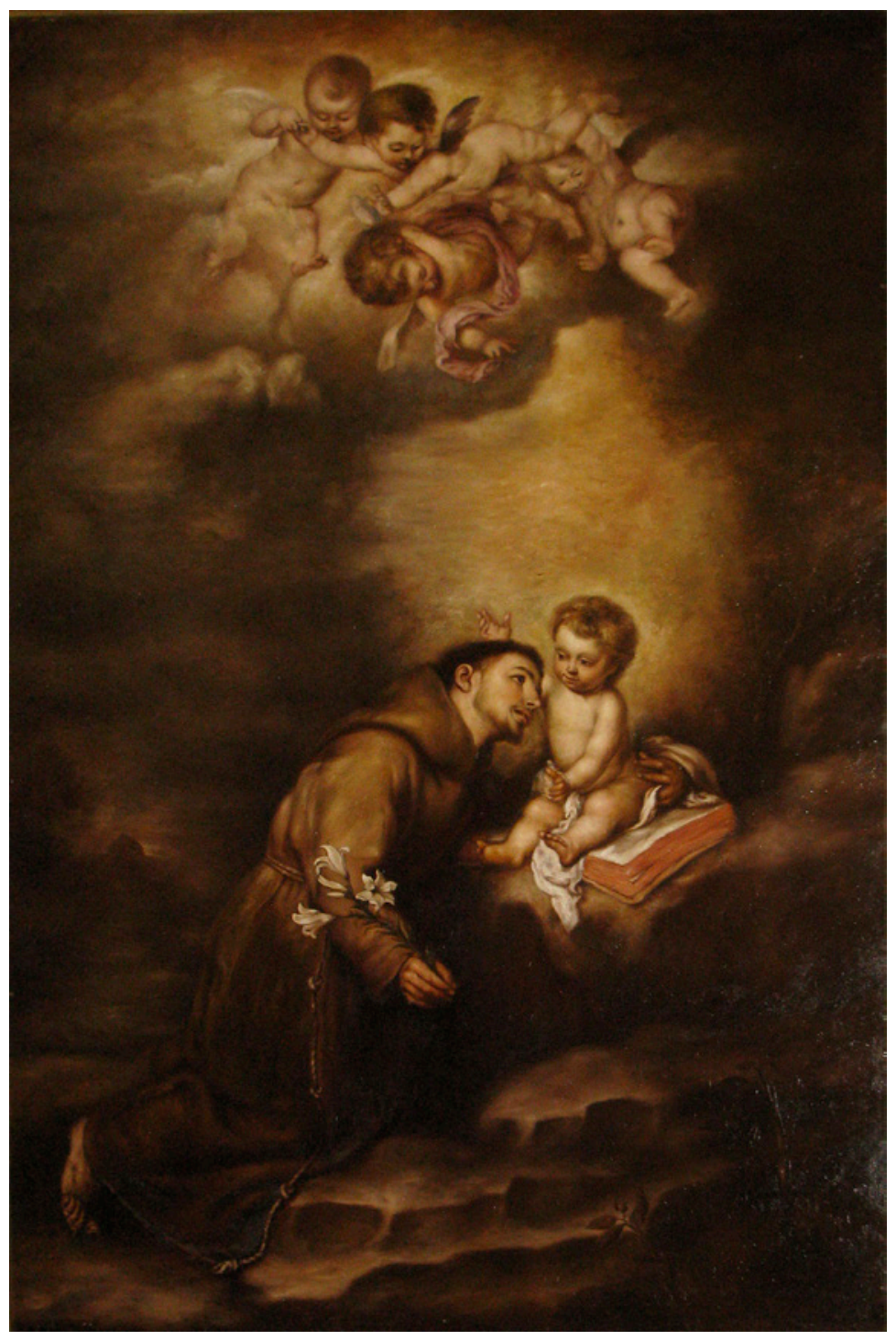

Figura. 7. San Antonio de Padua con el Niño. Fray Pedro de Madrid. 1917-1918. Iglesia de San Antonio de Pamplona. 


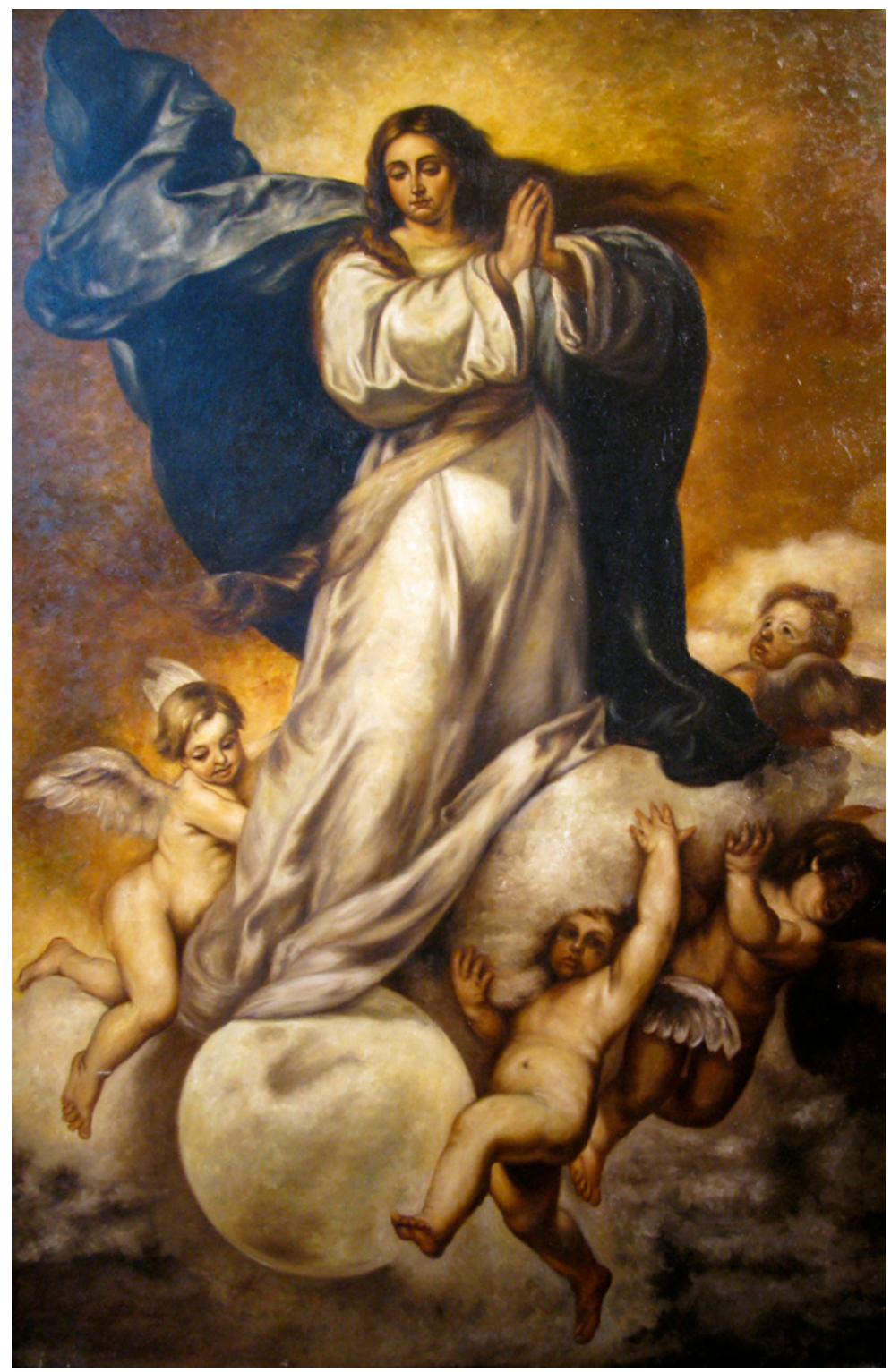

Figura. 8. Inmaculada Concepción. Fray Pedro de Madrid. 1917-1918. Iglesia de San Antonio de Pamplona. 


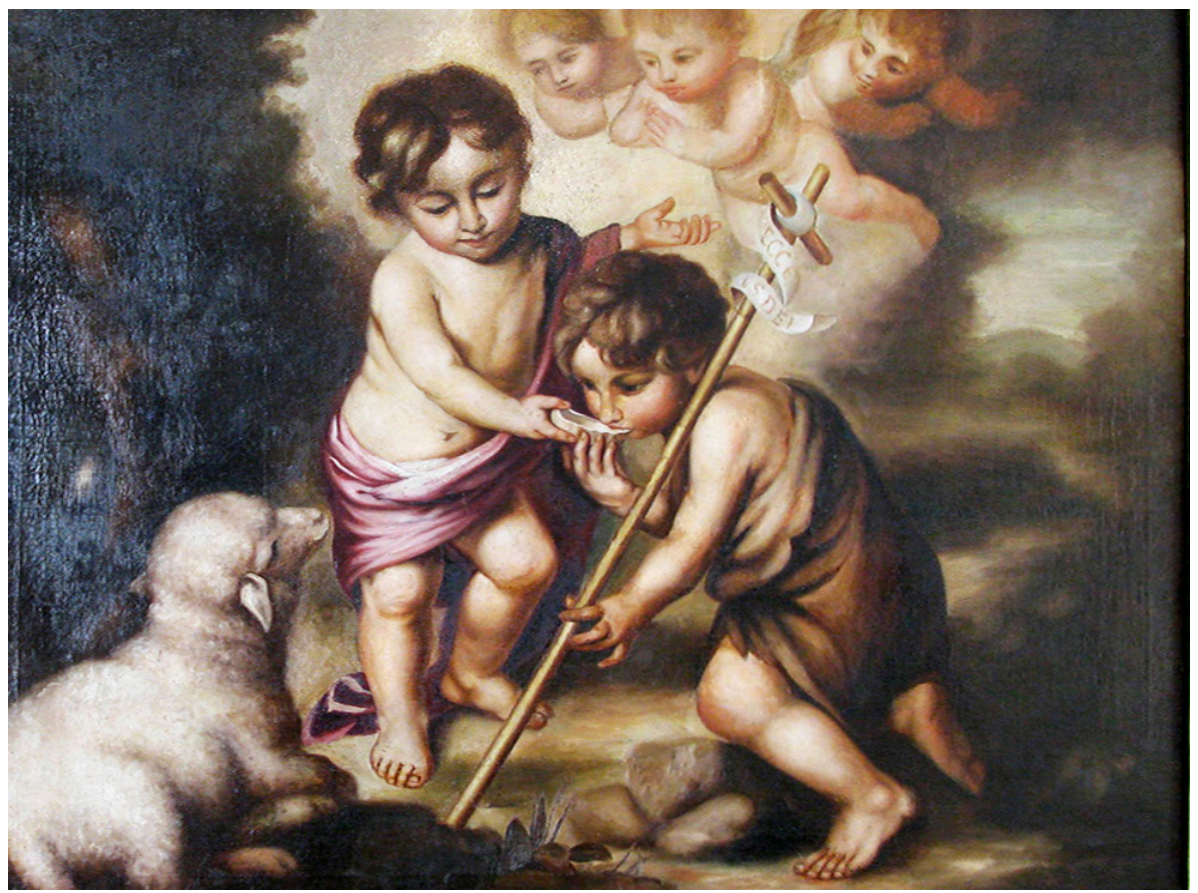

Figura. 9. Los niños de la concha. Fray Pedro de Madrid. 1912-1914. Convento de capuchinos de Sangüesa (Navarra). 

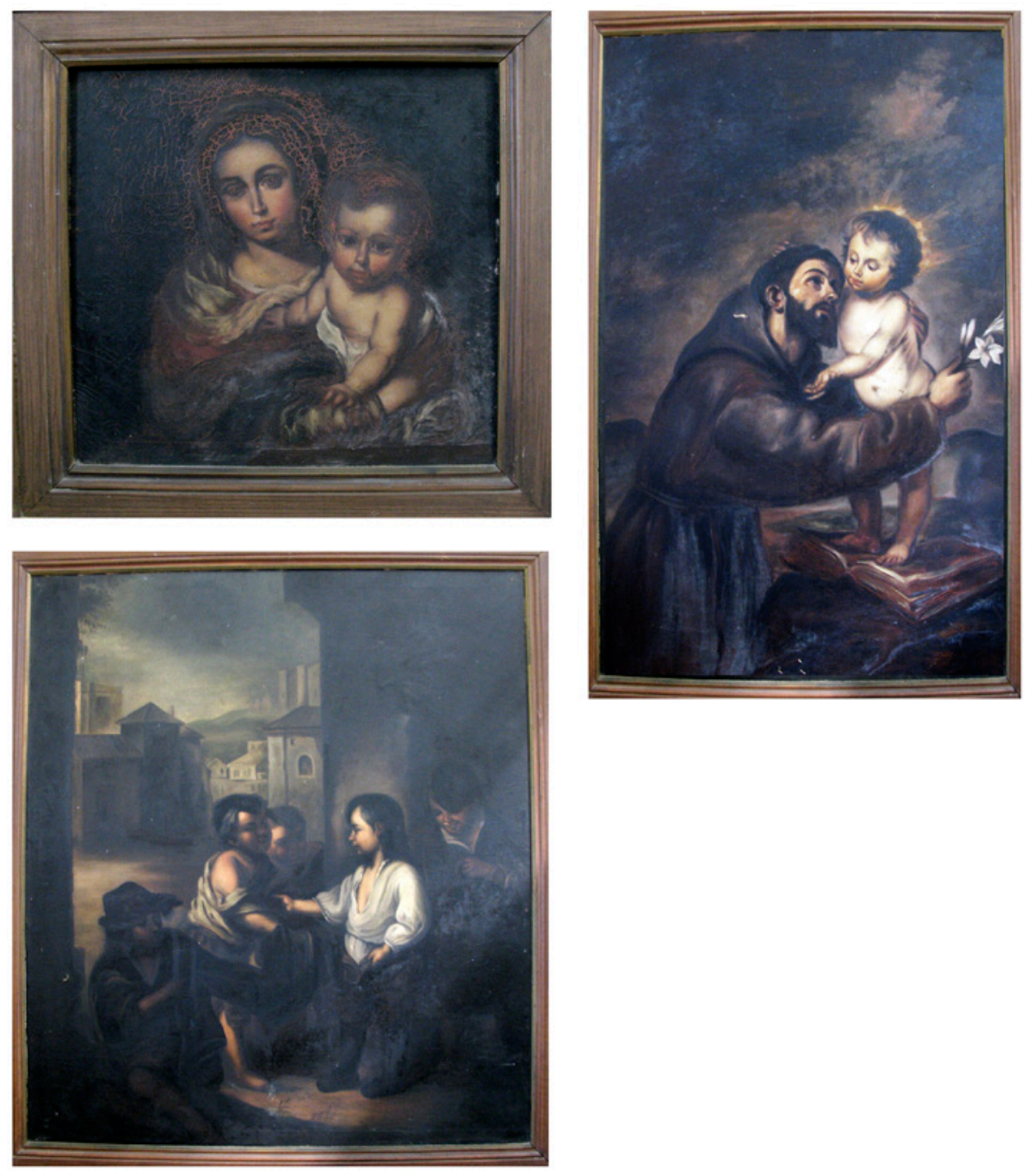

Figura. 10. La Virgen de la servilleta. San Antonio de Padua con el Niño. Santo Tomás de Villanueva niño repartiendo su ropa entre los pobres. Fray Pedro de Madrid. 1917-1918. Convento de capuchinos de Sangüesa (Navarra). 